\title{
'Such a fragile Thing as the human Countenance'. Irish Self-portraiture in the Eighteenth-Century
}

\section{Ruth Kenny}

\section{(2) OpenEdition \\ 1 Journals}

\section{Electronic version}

URL: http://journals.openedition.org/etudesirlandaises/5502

DOI: 10.4000/etudesirlandaises.5502

ISSN: 2259-8863

\section{Publisher}

Presses universitaires de Caen

\section{Printed version}

Date of publication: 30 May 2018

ISBN: 978-2-7535-7578-3

ISSN: 0183-973X

\section{Electronic reference}

Ruth Kenny, "'Such a fragile Thing as the human Countenance'. Irish Self-portraiture in the

Eighteenth-Century ", Études irlandaises [Online], 43-1 | 2018, Online since 30 May 2018, connection on 16 September 2019. URL : http://journals.openedition.org/etudesirlandaises/5502 ; DOI : 10.4000/ etudesirlandaises.5502

\section{This text was automatically generated on 16 September 2019}

(c) Presses universitaires de Rennes 


\title{
'Such a fragile Thing as the human Countenance'. Irish Self-portraiture in the Eighteenth-Century
}

\author{
Ruth Kenny
}

The self-portrait is a very special kind of work, a miraculous fusion of author and theme, of subject and object, always extremely rich in significance both hidden and manifest, in which every element has a precise reason for being ${ }^{1}$.

1 In an age ${ }^{2}$ characterised by the deliberate blurring of boundaries between the public and private spheres and a growing pre-occupation with the artistic process, it is perhaps not surprising that in eighteenth-century Europe it became almost obligatory for any artist of ambition to record their countenance for posterity ${ }^{3}$. While ostensibly the most personal form of artistic production -"the one form of easel painting that resists being owned"4self-portraiture in the eighteenth century became a public showcase and, as such, a cipher for a whole range of artistic aspirations and concerns. While Ireland is often seen as behindhand in terms of its engagement with the visual arts in this period-a viewpoint expressed as late as 1738 by patron of the arts and co-founder of the Dublin Society Dr Samuel Madden: "the utter Neglect [of painting and sculpture] which prevails in Ireland, will ever be a proof against us of Barbarism and Gothick ignorance" 5 -the enthusiastic participation of Irish painters in the European trend for self-representation appears to buck this assumption in an interesting manner. From the swagger of James Latham's authoritative image to Hugh Douglas Hamilton's tentative entry into the famed Uffizi collection; from Nathaniel Hone's self-conscious posturing to Thomas Frye's meditative self-scrutiny, this paper will examine how different eighteenth-century Irish artists approached the task of painting themselves. In doing so it will also consider the roles these images played within the different and evolving contexts of Dublin and London, to where so many Irish painters migrated. 
James Latham, Self-Portrait , c.1730, oil on canvas.

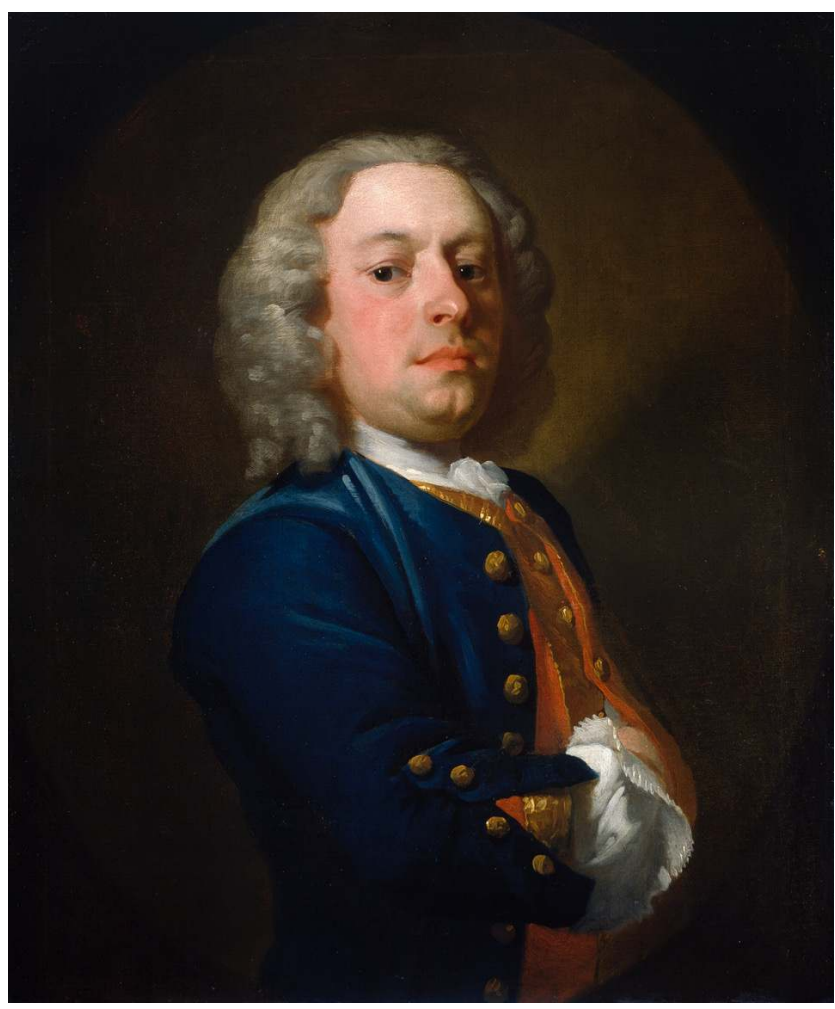

Photo (c) National Gallery of Ireland.

2 The earliest known example, produced and displayed in Ireland, of what could confidently be called the eighteenth century's defining genre, was James Latham's commanding self-portrait, painted c. $1730^{6}$. As a first foray, it was a bold statement of intent. Arms crossed and chin raised, Latham gazes imperiously at the viewer. Evidently well-fed and tending towards stoutness, with a phalanx of gold buttons catching the light and extravagant ruffles of lace escaping his sleeve-ends, he displays a supreme, almost antagonistic self-assurance. This is an impression borne out by what we know of his practice. For Latham, it appears, the artist's vision rather than the sitter's preference was of paramount importance. Renowned for his dogged pursuit of veracity, the unflattering realism of a painting such as Group Portrait with Mother and Child (Robert Wood Collection, Fota House) provides only one example of many; the slick of grease down a long nose, a stubborn double chin and a less than bonny baby all carefully noted. A well-known anecdote, courtesy of the pseudonymous contemporary commentator Anthony Pasquin (and thus probably embroidered), appears to confirm Latham's contemporary take on customer service:
A lady of distinction, with coarse lineaments, sat to him for her portrait which he drew faithfully; but she was so disgusted with the performance that she abused the painter, who immediately tore it from the frame and had it nailed to the floor of his hall as a piece of oilcloth. The consequence was that every person who came in knew the likeness, and the anecdote became so general that the mortified nymph repented her vain indiscretion and offered to buy the picture at any terms, which the artist peremptorily refused ${ }^{7}$.

Latham's self-portrait does not show us the artist at work. It does not reveal any part of the act of creation or give the viewer any kind of privileged access. The artist's firmly 
crossed arms keep us at a defensive distance, while his hands-the tools of his craft-are tucked securely into his sleeves and completely covered from view. This act of concealment is made all the more striking by the fact that Latham is now lauded for his facility in painting hands. As art historian Anne Crookshank noted, "hands are Latham's great achievement ${ }^{8}$ " and one has only to consider the intimate interlacing of fingers in Pole Cosby and his daughter Sarah or the elegant lassitude of Earl Stannard's elongated digits for confirmation of this fact. This is the artist as an equal to his clients, echoing in format the portraits of many of his eminent customers with the same three-quarter length halfturn and feigned oval.

Art historians Marcia Pointon and Kate Retford have variously demonstrated the importance of considering the particular location of artworks in any attempt to reconstruct their meaning in contemporary terms ${ }^{9}$. In this instance, we are fortunate enough to know that Latham's portrait came into the hands of fellow Dublin painter and admirer Philip Hussey, who displayed it in his Earl Street home from around the time of Latham's death in 1747, when Hussey probably acquired it, to the time of Hussey's own death, which occurred at his home in 1783. Said to have been "exceedingly valued by the possessor", Latham's portrait was presumably hung in a prominent place, for it is reported-again by Pasquin-that, from his lofty vantage point he presided in absentia over Dublin's mid-eighteenth century artistic gatherings for many years ${ }^{10}$. Every Sunday morning, under his watchful eye, "the literati and painters of Dublin... sat in judgement upon the relative occurrences of the week"11. Though, as previously noted, Pasquin's reputation often casts a doubt on the veracity of his observations, it seems fair to infer from them, in this instance, the powerful talismanic function of images such as Latham's ${ }^{12}$

5 It is a self-portrait which demonstrates the assurance of a man whose career was burgeoning. Latham had only set up shop in Dublin in 1725, approximately five years before this canvas was executed. Yet with little in the way of artistic competition, he soon dominated portrait production in the city in a way that was not possible for his London counterparts. Called rather flatteringly the 'Irish Van Dyck' (presumably in terms of his pre-eminence rather than his style $)^{13}$, contemporaries who could rival Latham's skill were thin on the ground. Anthony Lee (active 1724-67) was also based in Dublin and attracted some high profile business. Equally, Hugh Howard (1675-1737), though living in London, accepted a number of important portrait commissions in Ireland in the 1720s. However, he eventually turned to dealing and collecting amid rumours that he could not establish a sufficient reputation to support a viable studio ${ }^{14}$. Perhaps significantly, in terms of their artistic aspirations and engagement with the European mainstream, neither of them appear to have produced self-portraits. Francis Bindon (c. 1690-1765) "a gentleman amateur", better known for his architecture, produced paintings which were deemed "stiff, awkward and too inferior in quality to be included" in the pioneering 1969 'Irish Portraits' exhibition ${ }^{15}$. A very tentatively attributed self-portrait of Bindon, dating from c. 1720 , may be held by the National Gallery of Ireland. Whether or not this identification stands, its thin paint surface and hesitant style is a poor match for Latham's poised example.

While the English artist Stephen Slaughter's frequent trips to Dublin in the 1730s provided some competition in Latham's final years, his only serious rival for much of his career, in terms of clientele and in the field of self-portraiture, was Charles Jervas. Though firmly settled in London, Jervas often returned to Ireland for lengthy visits and 
could readily match Latham in terms of ambition and style. His 1725 self-portrait, produced in England at around the age of fifty, is a solid, bombastic image; the artist reclining comfortably against a backdrop of lustrous fabric, an indulgent smile playing on his lips. It reveals-much like Latham's self-portrait-a prosperous man who has reached the peak of his profession; not long appointed Principal Painter to the King and firmly established as the portraitist of preference for almost every person of consequence in the incumbent Whig government.

7 Known as a consummate self-promoter, it is curious to note that this is the only time Jervas appears to have turned the mirror on himself. The only caveat to the singularity of this portrait is a depiction of Elizabeth, Countess of Bridgewater, c. 1710-1720 in which the Countess stands beside a clavicytherium, or upright harpsichord. Jervas may have borrowed its appearance from a 1640 portrait of Marc'Antonio Pasqualini by Andrea Sacchi but in Jervas's version the carved bust of Apollo which decorates the side has been replaced by a man in an eighteenth century wig, who bears a strong resemblance to Jervas himself. His adulatory inclusion is said to reflect his well-known admiration for the Countess ${ }^{16}$.

8 These two examples may perhaps qualify Jervas in Latham's place as the first Irish selfportraitist, though both were produced in Jervas's London studio and the earlier of the two is highly elliptical. Leaving that particular jostle for primacy aside, both Latham and Jervas's depictions of themselves can be seen to function on a number of levels simultaneously; as a public statement of artistic intent, a spur to emulation and a wider reflection on the state of the arts in mid-eighteenth-century Ireland, at a time when they were generally understood to be at a low ebb. They deliberately concealed as much as they revealed, presenting to the viewer a mask-like façade of the artist as success-story.

9 Latham and Jervas's natural heirs were arguably Nathaniel Hone and James Barry who bestrode Irish self-portraiture in the second half of the eighteenth century like twin (though definitely non-identical) colossi. Both were prolific recorders of their own faces; Hone producing a succession of at least nine self-portraits and Barry at least six. Executed at fairly regular intervals and at key stages in their lives, no other Irish artists engaged in such extensive self-scrutiny. Within the context of an increasing diversification of the self-portrait genre, they retained the intense preoccupation with the role and status of the artist that flavoured the work of Latham and Jervas. However, they developed it through elaborate role-playing; Hone self-consciously trying out comparatively more prosaic parts-usually those of his social superiors -while Barry's fragile heroics encompassed more ambitious mythological characters.

10 Though Hone was born and trained in Dublin, he moved to England as a young man, in the early 1740 s, where he found work as an itinerant portraitist, firstly in the form of enamels and miniatures, and subsequently as an oil-painter. While his early self-portraits are relatively straightforward-the artist as a young man with an easel or holding a portfolio-his predilection for posing in fancy clothing was soon evident. A 1747 selfportrait finds the young Hone resplendent in a large fur hat and fur-trimmed coat.

11 As his reputation and status grew, Hone's conception of himself became more complex. In a 1768 self-portrait (Royal Academy London) he depicts himself in Van Dyck dress, conferring, by association, some of the lustre of his seventeenth-century artistic predecessor and the high social status of those who sat to him. A glimpse of blue sky and vine leaves behind him suggest a European setting, further lending the artist an international, cosmopolitan air. It is no coincidence that the year in which this portrait 
was painted was also the year in which Hone became one of the founding members of the newly established Royal Academy; a sure sign that he was now at the very centre of London's artistic world and undoubtedly a cause for commemorative celebration for this inveterate social-climber.

Seven years later, Hone's position had changed quite dramatically; a change that naturally inspired another self-portrait (National Gallery of Ireland). It depicts him c. 1775 as affluent and well-dressed, his walking stick planted firmly in the ground, which unfurls behind him to reveal a rolling Italianate landscape, complete with a classical temple. An unashamed exercise in self-aggrandisement, Hone had in fact never been to Italy (a situation which would have marked him out unfavourably from most of his artistic contemporaries). Yet 1775 was a year in which Hone needed to bolster his professional standing more than ever. Caught in the crossfire of a scandal of his ownundoubtedly calculated-making, Hone had blatantly attacked the president of the Royal Academy, Sir Joshua Reynolds, and was subsequently forced to battle for his own reputation. Having accused Reynolds of plagiarism by means of his now infamous painting The Conjuror, Hone was on the defensive. It is tempting to imagine that just as Reynolds was carefully preparing his own puff-piece self-portrait-wearing his Oxford doctoral robes, clutching a roll of paper invoking the name of Michelangelo-in his Leicester Fields studio, to send to the celebrated collection of self-portraits at the Uffizi, Hone was painting this self-portrait in nearby Pall Mall in riposte ${ }^{17}$. Indeed it may have been one of those included in his pioneering one-man show; a career retrospective which Hone mounted in rented rooms after removing his paintings from the Royal Academy's annual exhibition. Hone's rival display attracted large crowds and much press attention, thus providing an ideal platform for some of the posturing of which Hone was so fond ${ }^{18}$.

Hone's The Conjuror represents the culmination of a career-long rivalry with Reynolds and in fact constituted only one element in an entire nexus of practice which grew around and in opposition to the Royal Academy's opinionated president, the most prolific producer of self-portraits at this time (his tally numbered twenty-seven by the time of his death in 1792) ${ }^{19}$. In a brief detour, it is interesting to note here the curious work of another artist Strickland Lowry. An Englishman who settled in Ireland in his twenties, Lowry specialised in complex trompe l'œil paintings, all of which are undated though probably executed in the 1760s and 1770s. One of these depicted an engraving of Hone's painting The Spartan Boy pinned to a wooden board while another purported to show an engraving of a self-portrait by Reynolds, displayed in the same manner (both now in the National Gallery of Ireland collection) ${ }^{20}$. The fact that the 'engraving' in the latter does not correspond to any of Reynold's known self-portrait output complicates matters interestingly; it appears rather to be a 'self-portrait' of Reynolds which, though instantly recognisable, is of Lowry's own invention. 
Strickland Lowry, Trompe L'Oeil (Self Portrait), oil on canvas.

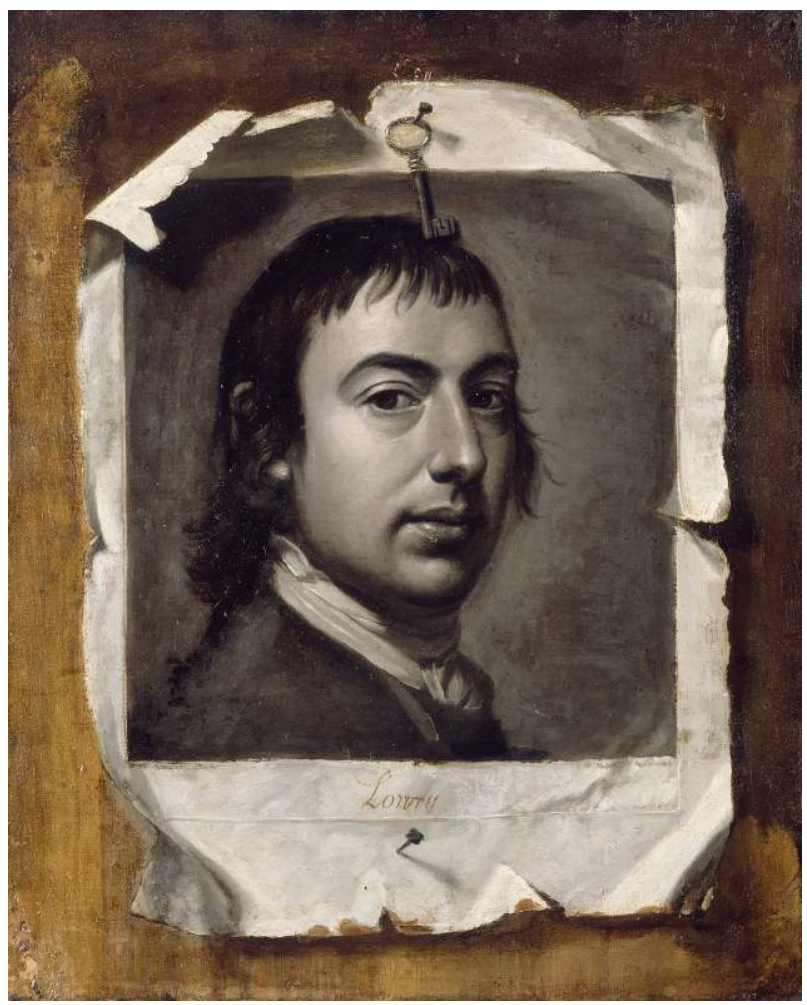

Photo (c) National Gallery of Ireland. engraving or original self-portrait can be traced. In an elaborate play on ideas of originality and reproduction, in such works Lowry skewers the very foundations of selfportraiture as the accurate depiction of an individual by his own hand; interrogating its representational function and in the process raising important philosophic questions about the nature of selfhood. It seems entirely appropriate that he should appropriate the face of the consummate self-promoter Reynolds as part of this innovative and strikingly modern endeavour.

Despite their evident differences, James Barry also shared Hone (and perhaps Lowry's?) antagonism towards Reynolds and increasingly, since his arrival from Ireland in 1764, he too found himself on the periphery of the London art world. Like Hone, he used selfportraiture to explore his position, though for very different reasons and with very different results. Far from trying to carve out a position for himself within the artistic elite, Barry's deliberate alienation from the establishment was a central tenet of his belief in the artist as suffering hero, willing to dispense with social norms and sacrifice material comforts in pursuit of artistic truth. Compositionally complex, multi-layered and didactic, Barry's self-portraits have many of the qualities of history paintings, as befitting an artist who scorned the contemporary predominance of unimaginative portrait painters-who "generally [had] no ideas of looking further than the likeness"-and primarily saw himself as a history painter ${ }^{21}$. For Barry, recording his own image for posterity was less a means of personal promotion and more a method of publicising his theories and stating an artistic creed. 
James Barry, Portrait of Burke and Barry in the Characters of Ulysses and a Companion fleeing from the Cave of Polyphemus, 1776, Oil on canvas

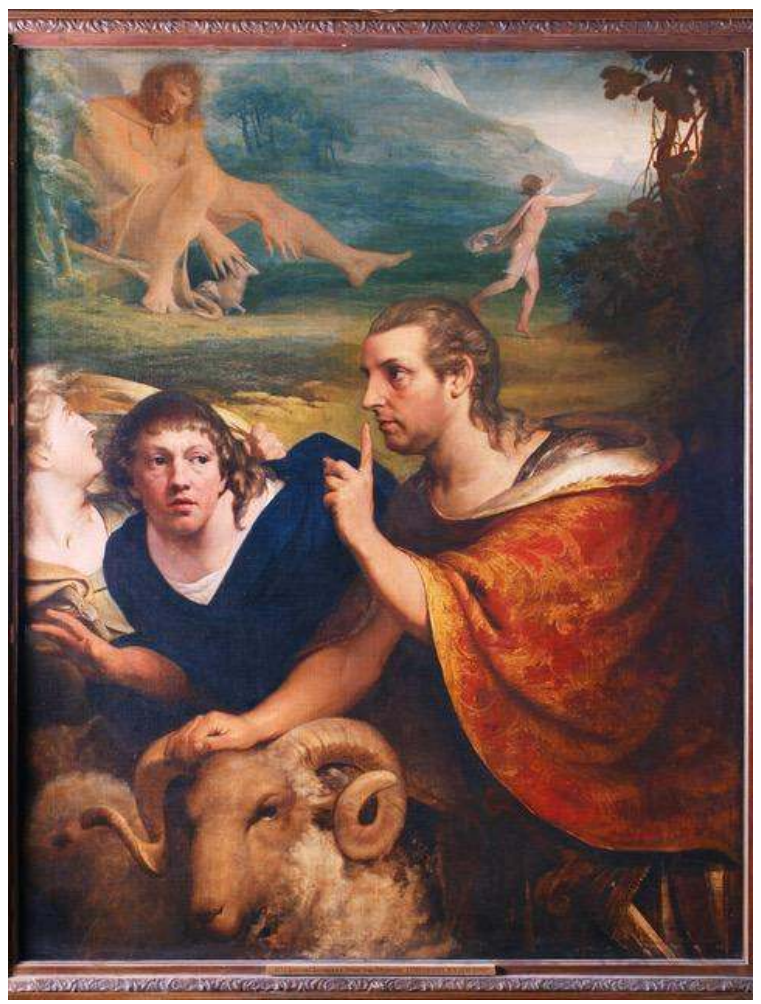

$127 \times 102 \mathrm{~cm}$. Collection: Crawford Art Gallery, Cork. Donated by the Friends of the National Collections of Ireland, 1956

His painting Ulysses and Polyphemus, executed in 1776, is a case in point; an allegorical work which skilfully combined classical mythology, autobiography and contemporary history. On one level it shows the classical hero Ulysses and a companion, who disguised themselves as sheep in order to escape from the cave of the blind giant Polyphemus. On a second level it is a friendship portrait of Barry with his patron and confidant, the statesman Edmund Burke. As such, it inserts itself into a long and august lineage of works, including portraits by artists such as Raphael, Annibale Carracci, Peter Lely and another self-portrait by Barry with his friends James Paine and Dominique Lefèvre (National Portrait Gallery, London). Perhaps as a demonstration of their intimacy, Barry's depiction of both himself and Burke is startlingly honest; the artist with puffy eyes and slack mouth; Burke in need of a shave with straggly hair and an exposed neck (a far cry from the decorous, buttoned-up stylings of Barry's formal portrait of Burke, executed five years previously). In a gesture suggesting a certain protectiveness towards his younger, fiery-tempered friend, Burke stretches out his arm to steady Barry's forward propulsion while holding a cautionary finger to his lips. In this respect, the danger represented by Polyphemus may be symbolic of the risk posed by Burkes' and Barry's joint opposition to what they perceived as the British government's mishandling of the American War of Independence. The Barry scholar, William Pressly also draws attention to a possible third reading of this complex picture by pointing out the beads of sweat on Barry's brow. As Pressly rightly points out, perspiring figures are far from common in art, with the important exception of Jesus on the cross. If Barry was equating his own sacrifices in the 
name of art to those of Jesus, it was certainly a bold claim, though he was undoubtedly committed to the idea of the artist as prophet and teacher ${ }^{22}$.

Such ideas were further explored in Barry's Self-portrait as Timanthes, which he started c.1780 and completed towards the end of his life in 1803. Taking an abandoned image of himself as a young man, the artist transformed it twenty years later into an autobiographical homage to the ancient Greek painter Timanthes, whose lost painting of a sleeping Cyclops, Barry reimagines and clutches tightly in his own canvas. By identifying himself with an artist described by Pliny as "highly gifted with genius... the only one among the artists in whose works there is always something more implied by the pencil than is expressed", Barry positioned himself as the true and faithful inheritor of the ideals of the classical world. This was in deliberate and provocative contrast to his artistic contemporaries, such as Reynolds, who had largely turned their backs on the increasingly unfashionable genre of history painting to pursue more commercial and lucrative avenues ${ }^{23}$. A stark illustration of the isolation and frustration of his final years, it is perhaps the most moving of all Barry's self-revelations; the last in a line of selfportraits which surely went far beyond those of any of his contemporaries to explore and exploit the possibilities of the human countenance.

In the hands of different practitioners, operating around the same time as Reynolds and Barry, a self-portrait could also be a mode of personal interrogation as much as a means of status affirmation or an expression of artistic principle. As producing a self-portrait became a more routine task, artists began to explore the possibilities of the genre more thoroughly. Rather than performing, some portraits in the second half of the century sought to disclose $\mathrm{e}^{24}$. The dominant note of both Thomas Frye and Robert Healy's remarkable self-portraits, dating from 1760, 1765 and 1766 respectively, is contemplative and self-revelatory. 


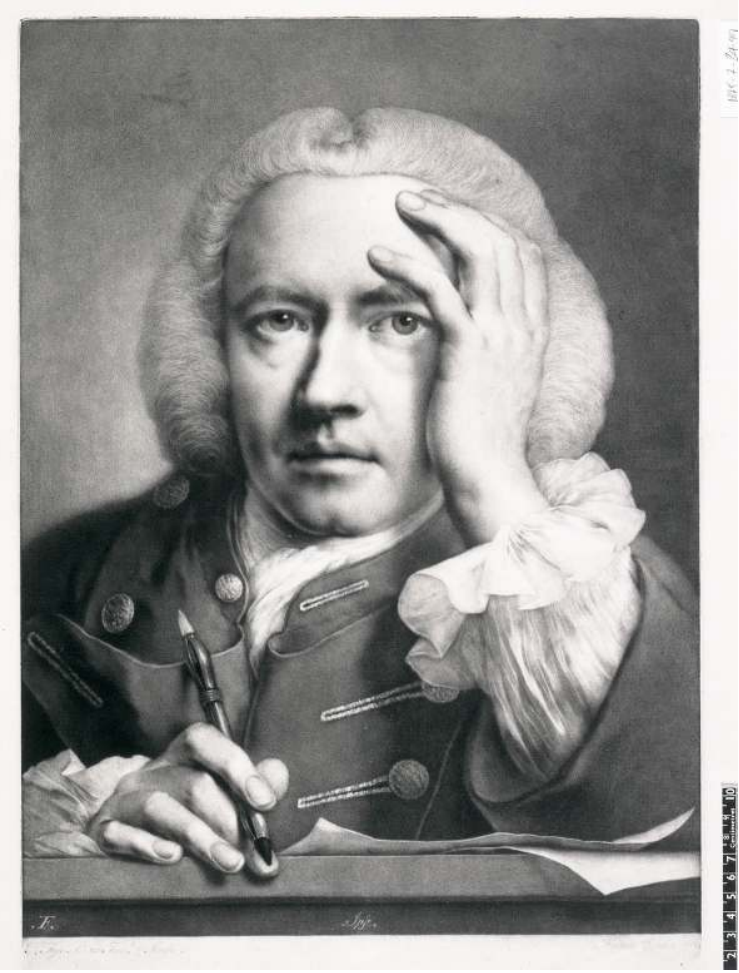

Mezzotint, $50.5 \times 35.0 \mathrm{~cm}$ (plate).

(C)Trustees of the British Museum.

Restrained to a black and white palette they eschew Reynolds' and Barry's rich colours for soft, tonal effects; Frye's those of mezzotint and Healy's those of grisaille chalk. Frye, the elder of the two and an undoubted influence on the younger Healy, produced his head as part of a series of "Twelve Mezzotinto Prints... drawn from nature and as large as life", which were sold by subscription through the Public Advertiser ${ }^{25}$. Born in County Offaly, but leaving Ireland for London at an early age, Frye has been described as "one of the most original and least standardised portrait painters of his generation" 26 . Yet he was perhaps better known among contemporaries as a successful entrepreneur, having established the innovative Bow Porcelain Factory in 1747. He thus easily rivalled Latham's or Hone's material success. Yet in choosing to record his own countenance after his retirement from the factory in 1759 on grounds of ill-health, he invokes a far more complex persona than that of a wealthy businessman. Employing an unusually large mezzotint plate to render his visage life-size, he faces the viewer pressed close to the picture-plane, with a direct, inquisitive gaze. Utilizing his considerable skills as an engraver, he displays a keen awareness of his own physicality; carefully rendering the fine, care-worn lines that furrow his brow and the network of veins that criss-cross the hand which supports his head, in a gesture somewhere between frank appraisal and resignation.

In contrast, Healy's pair of self-portraits show an artist at the very start of his career; similarly enquiring, but with a youthful, nervous energy lacking from Frye's example. Not long graduated, Healy turned to himself and his brother William as models, perhaps for want of a steady stream of clients. The earlier of the two drawings, executed when Healy was only 22 years of age, demonstrates his talent for creative draughtsmanship as he 
approaches the mirror at a sideways angle, as if unsure of what he will find. Yet to begin his exhibiting career (his first entry to the Society of Artists annual shows came the following year) and still awaiting a sizeable commission (he did not enter the employ of Thomas Conolly of Castletown, his first major patron until 1767) Healy was a man on the make; possessed of considerable gifts which had not yet taken full flight ${ }^{27}$. His second foray into self-scrutiny came the following year and displays a more direct confrontation with himself. Though he shows himself at work-a portfolio of drawings and a chalkholder clutched in his hand-the inclusion of a classical bust deliberately emphasizes his education and cultured status; its blank marble-eyed gaze forming a clever contrast with his bright, forward-looking stare.

Here we are offered a key to the difference between Healy's generation of young Dublin artists and their professional forebears. Healy was launching himself into an artistic milieu that had changed considerably since Latham and Jervas's time, and even Hone's. Perhaps most significantly for Healy, a year prior to his first self-portrait, a group of enterprising men had come together to establish the Society of Artists in Ireland; the first organization of its kind for Irish artists. Previously grouped with cutlers and stationers under the Guild of St Luke, this was a bold statement of intent on the part of twelve Dublin painters, who sought to raise their own status and promote fine art production in the city. Inspired by the success of the Society of Artists in London, founded four years previously, they placed an advertisement in the popular Dublin circular Faulkner's Journal in February 1764, calling for contributions to an annual exhibition-the first of its kind in Ireland-which it was hoped would "excite emulation" amongst themselves and "bring forth latent merit to public view". Healy's self-conscious attempt to ally himself with the Society's image of the artist-at one remove from other craftsmen-is played out in his studied allusion to classical sources and he undoubtedly benefited from the exciting and unprecedented opportunities created by these men. Combined with improved training facilities, in the form of the recently established Dublin Society Schools, which Healy (and Barry) had attended, it seems fair to say that Healy and his contemporaries had less need of the bombast and arrogance that Latham, in particular, had required to forge his career. As the Society of Artists exhibition catalogues reveal, late eighteenth-century Dublin was now a relative hive of creativity, with portraitists working alongside landscape artists, history painters, sculptors, printers and draughtsmen in a wide range of media, including oil paint, pastel, marble, wood, glass, wax and hair, to create an increasingly selfconfident national school of Irish art.

Yet, rather surprisingly, it was not until 1805 that an Irish artist's self-portrait finally joined Reynolds in the hallowed hang of the Corridoio Vasariano at the Uffizi; the ultimate accolade for any artist in the eighteenth and early nineteenth centuries. A small pastel portrait by Hugh Douglas Hamilton was at this time presented to the collection by Maria Louisa Bourbon, Queen Regent of Tuscany where it joined "the most eminent painters who have flourished in Europe during the last three centuries" 28 . In writing to thank her for the donation, Tomasso Puccini, then Director of the Uffizi, spoke of Hamilton as "The English [sic] painter... who has not been equalled in the last century in the art of pastels. I knew the artist in Rome, where he was most distinguished" 29.

Hanging alongside more than two hundred self-portraits by luminaries such as Rubens, Vandyke and Rembrandt and those of eminent contemporaries such as Reynolds, Raphael Mengs and Angelica Kauffmann, it is hard not to feel that Hamilton's contribution, executed c. 1785-90, is a rather timid foray, which must surely have been overshadowed 
by their more robust productions $\mathrm{s}^{30}$. This is a problem implicit in mixing pastel works with oil paintings in a hang, yet Hamilton's portrait suffers somewhat even in comparison to works by other pastellists represented in the collection. Measuring only $22 \times 20 \mathrm{~cm}$ Hamilton depicts himself elegantly but inconspicuously, slight of feature, in a palette of muted colours against a plain backdrop. Though superbly executed, as were all Hamilton's best pastels, with particular attention paid to the fine coating of powder in his hair and the frothy lace at his throat, the overall effect is one of polite restraint and a certain, impermanent fragility. Turning his head to one side, he appears to survey his neighbours, among them Rosalba Carriera's contribution, Self-Portrait with a Portrait of her Sister; a much more elaborate pastel characterised by sensitive detailing and measuring $71 \times 57 \mathrm{~cm}$. It shows Carriera half-length and at work, sticks of pastel heaped in front of a nearly finished drawing, a rose in her hair, dressed in lustrous silks and lace and with a hint of drapery in the bottom right hand corner. Hamilton also kept company with JeanÉtienne Liotard, whose pastel portrait was specially commissioned by Grand Duke Francis Stephen of Lorraine upon the artist's return from Constantinople in 1744. Also larger in scale, at $61 \times 49 \mathrm{~cm}$, it depicts Liotard resplendent in eastern dress, the almost tangible softness of his tall fur hat and the fine grey-streaked tangle of his beard demonstrating pastel technique at its very finest.

Of course, Hamilton was not to know the final destination of his work (it was, after all, not a specially commissioned portrait as so many of the others were) yet it is interesting to note that it was during the very period of its execution-the mid to late 1780s-that Hamilton was attempting to expand the limits of pastel beyond its small-scale, domestic and quickly-executed origins. In pursuit of a more elevated conception and finish, he produced a magnificent series of larger pastel full-length portraits of English and Irish Grand Tourists, which included exquisite topographical backgrounds and carefully studied contrasts in texture. This run of work culminated in his tour-de-force Antonio Canova in his Studio with Henry Tresham and a Plaster Model of the Cupid and Psyche Sculpture, c. 1788 (Victoria and Albert Museum), which is now considered "one of the finest works ever executed in the medium" ${ }^{31}$.

Hamilton's modesty in the face of such achievements was perhaps merely a product of his measured temperament (the Irish sculptor Christopher Hewetson, who lived in Rome at the same time as Hamilton, noted that Hamilton and fellow artist Jacob More were the only ones to keep a distance from the constant factioning and politicking of the different artistic groups in residence) $)^{32}$. Yet, as this essay has sought to demonstrate, his selfportrait does not seem representative of the growing sense of assertion among his Irish contemporaries, whose artistic productions were successfully moving out from under the shadow of their British and French contemporaries at this time. Confidently taking their place on the international stage, they seemed keen to disprove notions of eighteenthcentury Ireland as a derivative cultural backwater. However, while a range of Irish selfportraitists can be seen to have engaged in an original and meaningful way with a Europe-wide discourse of artistic self-examination during this period, it is perhaps telling that many of the fascinating images included in this brief survey are not already better and more widely known. 


\section{NOTES}

1. Silvia Meloni, 'The Collection of Painters' Self-Portraits' in Paintings in the Uffizi and Pitti Galleries, ed. Mina Gregori, Boston, New York, Toronto, London, Bullfinch Press, 1994, p. 596.

2. Title quote is taken from a Letter from James Barry to the Society of Arts, 2 May 1804. Royal Society of Arts, London. MS AD/MA/104/10/403.

3. For more on the characteristic and quite intentional confusion between the private / public spheres fostered in the second half of the eighteenth century see Jürgen Habermas, The Structural Transformation of the Public Sphere: An Inquiry into a Category of Bourgeois Society, Cambridge, Cambridge University Press, 1989, pp. 49-50 and Roger Chartier (ed.), A History of Private Life Volume III: Passions of the Renaissance, Harvard and London, Harvard University Press, 1989, pp. 161-397.

4. Philip Fisher quoted in James Hall, The Self-Portrait. A Cultural History, London, Thames and Hudson, 2014, p. 9.

5. Samuel Madden, Reflections and Resolutions proper for the Gentlemen of Ireland as to their Conduct for the Service of this Country, Dublin, 1738, p. 231.

6. While the identification of this portrait as Latham has only been in circulation since 1983, it is now widely accepted as such, not least by the National Gallery of Ireland, where it resides. Nicola Figgis and Brendan Rooney, Irish Paintings in the National Gallery of Ireland, Vol. 1, Dublin, National Gallery of Ireland, 2001, p. 255.

7. Anthony Pasquin [John Williams], Memoirs of the Royal Academicians and an Authentic History of the Arts in Ireland, London, H. D. Symonds, P. McQueen and T. Bellamy, 1796, p. 29. Pasquin's reputation as an arch satirist makes him a complex and fraught observer. Nonetheless, he remains the main source of information on Latham and indeed many other Irish artists of this period.

8. Anne Crookshank, 'James Latham 1696-1747', GPA Irish Arts Review Yearbook, Dublin, Eton Enterprises, vol. 5, 1988, p. 68.

9. Marcia Pointon, Hanging the Head: Portraiture and Social Formation in Eighteenth-Century England, New Haven and London, Yale University Press, 1993, p. 13. Kate Retford, 'Patrilineal Portraiture? Gender and Genealogy in the Eighteenth-Century English Country House' in John Styles and Amanda Vickery (eds.), Gender, Taste and Material Culture in Britain and North America 1700-1830, New Haven and London, Yale University Press, 2006, p. 315.

10. Anthony Pasquin, Memoirs, p. 10-11.

11. As a well-known figure in the Dublin arts scene for the extent of his stay-1780-84Pasquin most likely took part in Hussey's gatherings in Earl Street and Latham's continuing posthumous status was perhaps due, in no small part, to the constant reminder of his skills and pre-eminence that the prominent display of his self-portrait offered. 
12. Of course, the portrait under discussion here may, in fact, be only one of several selfportraits Latham produced and thus not the painting in Hussey's possession (Latham's total output was probably far higher than his extant paintings would suggest). Yet, as the only known survivor, it must - at least for the moment - stand for them all.

13. Anthony Pasquin, Memoirs, p. 29. Anne Crookshank and The Knight of Glin, The Painters of Ireland, c. 1660-1920, London, Barrie and Jenkins, 1978, p. 42.

14. George Vertue, The Note Books of George Vertue Relating to Artists and Collections in England, 6 vols, Oxford, The Walpole Society, 1930-5, vol. 3, p. 83.

15. Anne Crookshank and the Knight of Glin, Irish Portraits 1660-1860, London, Paul Mellon Foundation for British Art, 1969, p. 14.

16. With many thanks to Brendan Rooney for drawing the Countess of Bridgewater's portrait to my attention in this context.

17. Reynolds self-portrait was executed at the invitation of the Grand Duke of Tuscany. On the whole, Reynolds' self-portraits are not said to have detained him for long but he spent more time over this work, unusually rejecting his first effort. Hall, op. cit., p. 165.

18. For more on Hone's fascinating career see Nicola Figgis (ed.), Art and Architecture of Ireland. Vol. III Painting 1600-1900, Dublin, New Haven and London, RIA, Paul Mellon Centre, Yale University Press, 2014, pp. 309-312.

19. David Mannings, Sir Joshua Reynolds: A Complete Catalogue of his Paintings, 2 vols, Yale University Press, New Haven and London, 2000.

20. See Nicola Figgis and Brendan Rooney, Irish Paintings in the National Gallery of Ireland, Vol 1, p. 356 for more details of Lowry's self-portrait.

21. James Barry, An Account of a Series of Pictures in the Great Room at the Adelphi, London, 1783, vol. 2, p. 248 quoted in Liam Lenihan, The Writings of James Barry and the Genre of History Painting 1775-1809, Surrey, Ashgate, 2014, p. 40.

22. William Pressly, 'Barry's Self-Portraits: Who's Afraid of the Ancients?' in James Barry, 1741-1806: 'The Great Historical Painter', Kinsale, Gandon Editions for the Crawford Art Gallery, 2005, p. 67.

23. Pliny the Elder, Natural History, Book XXXV, p. 317. www.loebclassics.com, accessed January 2018.

24. Xanthe Brooke, Face to Face: Three Centuries of Artist's Self-Portraiture, Liverpool, National Museums and Galleries on Merseyside, 1994, p. 28.

25. Public Advertiser, 28 April 1760.

26. Ellis Waterhouse, The Dictionary of British $18^{\text {th }}$ Century Painters in Oils and Crayons, Woodbridge, Antique Collectors Club, 1981, p. 131.

27. Nicola Figgis (ed.), Art and Architecture of Ireland, pp. 293-4.

28. John Moore, A View of Society and Manners in Italy: with Anecdotes Relating to Some Eminent Characters, 3 vols, Dublin, Messrs Price, W. Watson, W. and H. Whitestone, Chamberlaine, Williams [and 17 others], 1781, vol. 2, p. 368.

29. Letter from Tomaso Puccini to Maria Luisa Bourbon, 21 Sept 1805, Archivio Soprintendenza alle Gallerie, Florence, MS 196 Fila 32, 49. Reproduced in Wolfram Prinz, Die Sammlung der Selbstbildnisse in der Uffizien Berlin, Gebrüder Mann, 1971, p. 222. 
30. John Moore, in A View of Society, numbers the collection as such in 1781, with presumably a few more additions between that date and Hamilton's entry in 1805. It now numbers more than 2,000 works.

31. Katie Coombs, manuscript acquisition notes in the Canova and Tresham file at the Victoria and Albert Museum, London, where the pastel now hangs as a centrepiece of the British Galleries display.

32. Letter from Christopher Hewetson to George Cumberland, 4 May 1792, Cumberland Papers, British Library Add MS 31496, f. 333.

\section{ABSTRACTS}

Through the works of James Latham, Charles Jervas, Thomas Frye, Robert Healy, Nathaniel Hone, James Barry, Strickland Lowry and Hugh Douglas Hamilton, this essay seeks to explore how Irish self-portraits keyed into a wider, international vogue for artistic self-examination during the eighteenth century. Necessarily touching on practical questions of display, dissemination and reception, it will also examine the polarities of disclosure and performance, friendship and alienation, temporality and permanence, emulation and originality which the genre generously encompassed. In doing so, parallels will be drawn with other contemporary self-portrait practitioners, with particular attention drawn to the work of Joshua Reynolds, the most prolific producer of self-portraits at this time.

En s'appuyant sur l'œuvre de James Latham, Charles Jervas, Thomas Frye, Robert Healy, Nathaniel Hone, James Barry, Strickland Lowry and Hugh Douglas Hamilton, cet article vise à démontrer que les autoportraits réalisés par les peintres irlandais du 18è siècle s'inscrivent dans un mouvement plus large qui atteste de l'engouement de l'époque pour l'étude de soi à travers l'art. Prenant nécessairement en compte des aspects pratiques liés à l'exposition des œuvres, à leur dissémination et à leur réception, nous étudierons aussi des oppositions binaires entre dévoilement et mise en scène, amitié et désunion, temporalité et permanence, émulation et originalité que ce genre pictural embrasse généreusement. Au fil de l'analyse, des parallèles seront effectués avec d'autres autoportraitistes contemporains, au premier rang desquels Joshua Reynolds, qui réalisa le plus d'autoportraits à l'époque.

\section{INDEX}

Keywords: eighteenth Century, Dublin, London, oil painting, pastel

Mots-clés: dix-huitième siècle, Dublin, Londres, peinture à l'huile, pastel 
AUTHOR

RUTH KENNY

University College Dublin. Dr Ruth Kenny is a curator and art historian who has worked at Tate Britain and the National Portrait Gallery. She is currently curator of an exhibition on the Society of Artists in Ireland for the Irish Georgian Society and teaches at the School of Art History and Cultural Policy, University College Dublin. 